\title{
IMPLEMENTATION OF EDUCATION PLANNING IN IMPROVING EDUCATIONAL QUALITY THROUGH 2013 CURRICULUM BASIC SCHOOL
}

\section{Ima Hariyanti Ningsih, Retno Winarni, Roemintoyo}

Universitas Sebelas Maret

rymarhiyanti@gmail.com

\section{Article History}

accepted 09/07/2018

approved 01/08/2018

published 17/09/2018

\section{Keywords}

planning, improving

curriculum educational, 2013

\begin{abstract}
Planning is the element and function of management the first and main among other management functions, so that in the field of education becomes the key implementation of educational activities to achieve educational goals for each type and a certain level of education. The purpose of this research is to know the implementation of education planning in SDN 02 Jetis. This research uses descriptive qualitative approach which has natural characteristic as direct data source. The data in this research is taken from observation, interview, and documentation. Research findings are vision planning, mission and school objectives, quality improvement through training of educators and learners. Apply the 2013 curriculum well to cultivate a social, insightful and creative attitude towards learners. See from the growing competence of teachers, the ability of students learn both from the academic and non-academic side showed improvement, and relationships with related institutions, parents learners more closely.
\end{abstract}

Social, Humanities, and Education Studies (SHEs): Conference Series https://jurnal.uns.ac.id/shes

p-ISSN 2620-9284

e-ISSN 2620-9292 


\section{PENDAHULUAN}

Perencanaan merupakan proses yang rasional dan sistematis dalam menetapkan langkah-langkah kegiatan yang akan dilaksanakan guna mencapai tujuan yang telah ditetapkan. Pernyataan tersebut didukung oleh Abdulmuid (2013) Perencanaan dikatakan sebagai pemikiran masa depan, sebagai pengendali masa depan, sebagai pembuat keputusan menyeluruh disemua sektor manajemen pendidikan.

Fattah (2013) perencanaan adalah tindakan menetapkan terlebih dahulu apa yang akan dikerjakan, bagaimana pengerjaannya, apa yang harus dikerjakan, dan siapa yang mengerjakannya. Dalam setiap perencanaan selalu terdapat tiga kegiatan yang meskipun dapat dibedakan tetapi tidak dapat dipisahkan. Kegiatan tersebut meliputi: (1) perumusan yang ingin dicapai; (2) pemilihan program untuk mencapai tujuan itu; (3) identifikasi dan pengerahan sumber yang jumlahnya selalu terbatas.

Undang-Undang Sistem Pendidikan Nasional Nomor 20 Tahun 2003 Pasal 1 Ayat 1 menyatakan bahwa "pendidikan adalah usaha sadar dan terencana untuk mewujudkan suasana belajar dan proses pembelajaran agar peserta didik secara aktif mengembangkan potensi dirinya untuk memiliki kekuatan spiritual keagamaan, pengendalian diri, kepribadian, kecerdasan, akhlak mulia, serta keterampilan yang diperlukan dirinya, masyarakat, bangsa dan negara". Berdasarkan penjelasan dalam undang-undang tersebut, maka pendidikan adalah usaha terencana untuk mewujudkan proses pembelajaran yang meliputi adanya pendidik dan peserta didik dalam rangka meningkatkan potensi dan membentuk totalitas peserta didik sebagai individu. Pendidikan merupakan interaksi manusiawi yang ditandai keseimbangan antara kedaulatan subjek didik dengan kewibawaan pendidik. Pendidikan meningkatkan kualitas kehidupan pribadi masyarakat. Pendidikan juga berlangsung sepanjang hayat.

Sutomo (2012) Perencanaan pendidikan adalah keputusan yang diambil untuk melakukan tindakan selama waktu tertentu agar penyelenggaraan sistem pendidikan menjadi lebih efektif dan efisien, serta menghasilkan lulusan yang bermutu, dan relevan dengan kebutuhan masyarakat. Perencanaan pendidikan adalah proses intelektual yang berkesinambungan dengan berorientasi pada pelaksanaan kegiatan pendidikan. Pendapat Sutomo didukung oleh pernyataan Damavandi (2011) "Educational planning is a kind of problem solving effort aimed at human needs fulfillment. In learning, any facilitating factor is included in educational planning consisting of different components such as objectives, presentation \& web classification". Perencanaan pendidikan adalah semacam upaya pemecahan masalah yang ditujukan untuk pemenuhan kebutuhan manusia. Dalam pembelajaran, setiap faktor fasilitasi termasuk dalam perencanaan pendidikan yang terdiri dari berbagai komponen seperti tujuan, presentasi \& klasifikasi web.

Rojiun (2012) Perencanaan pendidikan adalah proses intelektual yang berkesinambungan dalam menganalisis, merumuskan, menimbang, dan membuat keputusan yang konsisten serta berhubungan secara sistematis dengan keputusan

lain. Perencanaan pendidikan memiliki hubungan yang sistematis dan berkesinambungan untuk mewujudkan tujuan pendidikan.

Berpijak pada pemaparan di atas perencanaan pendidikan adalah proses yang berkesinambungan untuk mempersiapkan masa depan yang bersifat rasional dan sistemik dalam hal menentukan kebijakan, prioritas dan biaya pendidikan secara efektif dan efisien untuk mencapai tujuan yang telah ditetapkan yang bersumber pada kebutuhan.

Kebutuhan akan perencanaan muncul sebagai akibat semakin intensif dan kompleksnya permasalahan yang terjadi dalam masyarakat. Permasalahan terjadi karena adanya suatu aktivitas atau kejadian menyimpang dari yang seharusnya terjadi, seperti adanya penurunan sumber daya, kesalahan dalam penggunaan perkembangan ilmu pengetahuan, rendahnya hasil output dalam sistem pendidikan, dan hambatan 
dalam pencapaian tujuan pendidikan.Hal tersebut terjadi karena unsur perencanaan pendidikan masih lebih banyak dijadikan faktor pelengkap kebijakan pimpinan. Selain itu, para perencana pendidikan masih kurang memahami proses dan mekanisme perencanaan dalam konteks yang lebih komprehensif.

Kurikulum 2013 merupakan salah satu dari perencanaan pendidikan yang berguna untuk meningkatkan mutu pendidikan. Kurikulum 2013 memiliki pengertian salah satu komponen pendidikan yang dipandang sangat penting dan bila terjadi perubahan terhadap perubahan kurikulum maka akan berdampak pada penataan komponen pendidikan (Sutjipto, 2014). Dalam Undang-Undang Nomor 20 tahun 2003 tentang Sistem Pendidikan Nasional, kurikulum dinyatakan sebagai seperangkat rencana dan pengaturan mengenai tujuan, isi, dan bahan pelajaran serta cara yang digunakan sebagai pedoman penyelenggaraan kegiatan pembelajaran untuk mencapai tujuan pendidikan tertentu. Kurikulum sebagai acuan untuk menentukan perubahan pendidikan kearah yang lebih baik. Melalui kurikulum dapat membentuk sikap, menambah wawasan pengetahuan, dan krativitas. Keseluruhan hal tersebut dapat tercapai melalui kurikulum 2013.

Menurut Fadlillah (2014) kurikulum 2013 merupakan sebuah kurikulum yang dikembangkan untuk meningkatkan dan menyeimbangkan kemampuan soft skill dan hard skill yang berupa sikap, keterampilan dan pengetahuan. Senada dengan Arnhida (2018) Kurikulum 2013 sendiri merupakan sebuah kurikulum yang mengutamakan pada pemahaman, skill dan pendidikan karakter, dimana siswa dituntut untuk paham atas materi, aktif dalam proses berdiskusi dan presentasi serta memiliki sopan santun dan sikap disiplin yang tinggi.

Kurikulum 2013 berusaha untuk lebih menanamkan nilai-nilai yang tercermin pada sikap dapat berbanding lurus dengan keterampilan yang diperoleh peserta didik melalui pengetahuan dibangku sekolah. Dengan kata lain, antara soft skills dan hard skills dapat tertanam secara seimbang, berdampingan, dan mampu diaplikasikan dalam kehidupan sehari-hari. Dengan adanya kurikulum 2013 diharapkan peserta didik dapat memiliki kompetensi sikap, keterapilan, dan pengetahuan yang meningkat dan berkembang sesuai dengan jenjang pendidikan yang telah ditempuhnya .

Pendidikan tidak hanya dilihat dari pengetian pencapaian tujuan yang telah dibuat, melainkan pencapaian tujuan yang bermanfaat untuk melatih kemandirian dan kreativitas peserta didik agar mampu bersaing di dunia luar. Sehingga perencanaan pendidikan dihubungkan dengan kurikulum 2013 yang sesuai untuk menumbuhkan dan mengasah kreativitas, kemandirian, keaktifan dan peduli sosial.

Berdasarkan hasil dari observasi awal ditemukan beberapa fakta di lapangan terkait peencanaan pendidikan. Pertama mengenai perencanaan awal yang dibuat belum sesuai dengan keadaan yang ada dan kedua ditemukannya sumber daya yang belum memadai dalam bidangnya.

\section{METODE}

Metode yang digunakan dalam mini research ini menggunakan metode kualitatif. Memiliki karakteristik alami (natural setting) sebagai sumber data langsung, deskriptif, proses lebih dipentingkan dari pada hasil, analisis dalam penelitian kualitatif cenderung dilakukan secara analisa induktif dan makna merupakan hal yang esensial.

Teknik analisis data yang digunakan yaitu mengguanakan teknik analisis data Milles dan Huberman (2007) yang terdiri dari: (1) reduksi data, (2) mendisplay data, (3) penarikan kesimpulan atau verifikasi. Pada tahap reduksi data menunjuk pada proses pemilihan pemfokusan, penyederhanaan abstraksi data mentah yang diperoleh dari catatan-catatan lapangan yang tertulis. Reduksi data dapat terjadi secara kesinambungan. Reduksi data adalah pengumpulan data berproses, terdapat beberapa episode. Reduksi data membuat rangkuman, pengkodean, membuat tematema, membuat gugus-gugus, membuat pemisahan, dan membuat memo. Reduksi 
data merupakan proses terus menerus setelah kerja lapangan hingga laporan akhir lengkap.

\section{HASIL DAN PEMBAHASAN}

Sekolah Dasar Negeri 02 Jetis memiliki visi : "terwujudnya peserta didik yang unggul dalam IPTEK, beriman, cerdas, terampil, mandiri dan berbakat". Adapun misinya adalah Menanamkan keimanan dan ketuhanan melalui pengamalan ajaran agama, mengoptimalkan proses pembelajaran dan bimbingan untuk meningkatkan kecerdasan spiritual, intelektual, dan emosi, mengembangkan bidang IImu Pengetahuan dan Teknologi (IPTEK), berdasarkan minat, bakat, potensi peserta didik, membina kemandirian peserta didik melalui kegiatan pembiasaan dan pengembangan diri yang terencana dan berkesinambungan, melaksanakan kegiatan akstrakurikuler dan pendidikan keterampilan sebagai bekal kehidupan pada masa depan, melaksanakan kegiatan pembiasaan dan keteladanan dalam pembentukan karakter peserta didik yang kuat, menjalin kerjasama yang humoris antara warga sekolah, masyarakat dan lembaga lain yang terkait".

Visi dan misi dibentuk karena dilatar belakangi oleh kemajuan teknologi yang semakin pesat. Hal itu pula berdampak pada perencanaan pendidikan yang berada pada SDN 02 Jetis. Perencanaan pendidikan di SD tersebut dibentuk sebelum memasuki tahun ajaran yang baru, lebih tepatnya pada waktu liburan semester genap dan setelah dilakukannya evaluasi pelaksanaan perencanaan pendidikan yang telah dilaksanakan sebelumnya. Berdasarkan data yang diperoleh dari hasil evaluasi dapat menentukan perencanaan yang baru untuk lebih memajukan lembaga pendidikan tersebut.

Perencanaan pendidikan pada SDN 02 Jetis dilakukan secara menyeluruh, baik dari sisi akademiknya dan non akademik. Dari sisi akademiknya dengan perencanaan kurikulum, perencanaan kurikulum di sekolah ini mengacu kepada standar kurikulum nasional atau yang telah ditetapkan oleh pemerintah. Sekolah ini menggunakan kurikulum 2013, melalui kurikulum tersebut dapat membantu peserta didik untuk aktif, percaya diri, memiliki wawasan yang luas dan terampil. Hal itu dibuktikan melalui prestasi yang telah diraih oleh peserta didik melalui siswa yang berprestasi untuk diikutsertakan dalam perlombaaan ditingkat kabupaten dan memberikan ekstakurikuler pada peserta didik. Keterberhasilan pelaksanaan perencanaan dalam pendidikan di SDN 02 Jetis dibuktikan dari tahun ke tahun ada peningkatan, baik dari segi pendidikan, beragam prestasi yang di peroleh, hasil lulusannya yang terus meningkat dan bertambahnya alat penunjang keterberhasilannya seperti alat peraga, alat musik. Non akademiknya melalui ekstrakurikuler seperti pramuka dan rebana. Melalui kedua kegiatan tersebut peserta didik dapat menuangkan bakat dan minatnya.

Perencanaan pendidikan yang dibuat tidak hanya untuk peserta didik namun diberikan pula pada tenaga pendidik, yaitu adanya pelatihan pada guru berupa seminar, pelatihan menulis PTK yang baik, memberikan latihan bagi dan semakin mahir dan terampilnya guru dalam memanfaatkan teknologi dalam KBM. Dalam hal ini membantu untuk mewujudkan pembelajaran yang efektif dan menarik untuk peserta didik dan membantu meningkatka mutu pendidikan mellui prestasi yang diraihnya.

Terlepas dari perencanaan yang dapat dilaksanakan dengan baik, terdapat kendala-kendala yang dihadapi selama dalam pelaksanaan perencanaan dalam pendidikan yang telah dibuat. Salah satu kendala tersebut yaitu peran serta orangtua peserta didik yang belum optimal. Disebabkan oleh ketidaksamaan karakteristik dari setiap orang tua peserta didik dan tingkat perhatian terhadap anak berbeda antara orang tua satu dan orang tua yang lainnya.

Melalui rencana kerja tahunan yang telah dibuat tidak hanya visi dan misi yang tercapai, namun juga dapat meningkatkan mutu pendidikan yang terdapat pada sekolah tersebut. Yani (2017) menjelaskan bahwa dalam hal peningkatan mutu 
layanan, sekolah juga melakukan pembinaan karakter peserta didik dengan membuat tata tertib peraturan bagi peserta didik. Hal ini juga memiliki makna bahwa sekolah berusaha menciptakan sebuah lingkungan pendidikan yang baik dan berkarakter, sehingga mutu layanan pendidikan di sekolah tersebut dapat terwujud secara optimal. Mengingat salah satu karakteristik dari kurikulum 2013 yaitu mengembangkan sikap spiritual dan sosial, rasa ingin tahu, kreativitas, kerja sama dengan kemampuan intelektual dan psikomotorik secara seimbang (Widyastono, 2014). Salah satu contoh untuk meningkatkan mutu layanan pendidikan yaitu dengan adanya layanan UKS untuk kesehatan para peserta didiknya, layanan perpustakaan untuk pengembangan literasi dan layanan BP untuk memberikan solusi pada setiap permasalahan yang dihadapi peserta didik.

Tidak lupa dengan pengembangan peserta didik dalam hal kognitifnya, selain dengan perencanaan yang telah dibuat oleh guru untuk proses pembelajaran juga telah membuat perencanaan yang berupa seleksi untuk sisiwa teladan dan beasiswa. Sehingga perencanaan yang telah dibuat juga diterapkan dengan sebaik-baiknya.

\section{SIMPULAN}

Hasil wawancara yang dilakukan dapat diketahui bahwa perencanaan dalam pendidikan yang dibuat serta pelaksanaannya sudah baik, dan selalu menunjukkan kemajuan dalam setiap tahunnya. Dilihat dari kompetensi guru, kemampuan peserta didiknya baik dari sisi akademik dan non akademiknya dan hubungan dengan instansi terkait, orangtua peserta didik, alumni, dan komite sekolah semakin erat serta peningkatan mutu pada sekolah tersebut setiap tahunnya meningkat.

\section{DAFTAR PUSTAKA}

Abdulmuid, Muhibbudin. 2013. Manajemen Pendidikan. Jawa Tengah: Penging Mangkunegaran. [berkas PDF]

Atmodiwirjo, Subagio. 2000. Manajemen Pendidikan Indonesia. Jakarta: Ardadizya Jaya.

Arnidha, Yunni dan Ana Istiani. 2015. Pendampingan Implementasi Kurikulum 2013 Bagi Guru Sekolah Dasar di Kecamatam Negerikaton Kabupaten Pesawaran Propinsi Lampung. International Journal of Community Service Learning Volume 2, Number 1, 2018, pp. 16-21

Damavandi. 2011. The analysis of correlation between Information Technology (IT) and educational planning. Procedia Computer Science 3 (2011) 1517-1519

Fadlillah. 2014. Implementasi Kurikulum 2013 Dalam Pembelajaran SD/MI, SMP/MTS, SMA/MA. Yogyakarta: AR-RUZZ Media

Fattah, Nanang. 2013. Landasan Manajemen Pendidikan. Bandung: PT Remaja Rosdakarya

Kusnawan, Aep. 2010. Perencanaan Pendidikan Tinggi Dakwah Islam. Jurnal IImu Dakwah Vol. 4 No. 15 Januari-Juni 2010

Milles, Matthew B. dan Michael Huberman. 2007. Analisis Data Kualitatif. Jakarta: UI Press

Moleong, Lexy J. 2016. Metodologi Artikel Kualitatif. Bandung: Remaja Rosdakarya

Pitono, Lukito Lebdo. 2013. Proses Dan Implementasi Perencanaan Pendidikan (Dalam Rangka Pelaksanaan MBSP Di Satuan Pendidikan Islam X). Jurnal Of Empirical Research Islamic Education Vol.1 No. 1 Hal. 221-234

Rojiun. 2012. Perencanaan Pendidikan Berbasis Masyarakat. Journal Educational Management 1 (2) (2012)

Sa'ud, Udin Syaefudin \& Makmun, Abin Syamsuddin. 2011. Perencanaan pendidikan: Suatu Pendekatan Komprehensif. Bandung: PT Remaja Rosdakarya

Sa'ud, Udin Syaefudin \& Makmun, Abin Syamsuddin. 2009. Perencanaan Pendidikan, Bandung: PT Remaja Resdakarya 
Suhardan, Dadang dan Nugraha Suharto. 2009. Manajemen Pendidikan. Bandung: Alfabeta Sugiyono. 2015. Metode Artikel Pendidikan Pendekatan Kuantitatif, Kualitatif, dan $R \& D$. Bandung Alphabeta

Sutomo, dkk. 2012. Manajemen Sekolah. Semarang. UNES Press

Soemantri, Manab. 2013. Perencanaan Pendidikan. Bogor. IPB Press. [berkas PDF]

Undang-Undang Republik Indonesia Nomor 20 Tahun 2003 Tentang Pendidikan Nasional

Widyastono, Herry. 2014. Pengembangan Kurikulum Era Otonomi Daerah dari Kurikulum 2004, 2006, ke Kurikulum 2013. Jakarta: Bumi Aksara

Yani, Yuli. 2017. Implementasi Perencanaan Pendidikan Dalam Meningkatkan Mutu Layanan Pendidikan Di Smp Nahdhatul Ulama Medan Helvetia. Jurnal Manajemen Pendidikan Islam Vol 1. No 1. Juli - Desember 2017 Halaman 22 30 ISSN. $3459-2461$ 